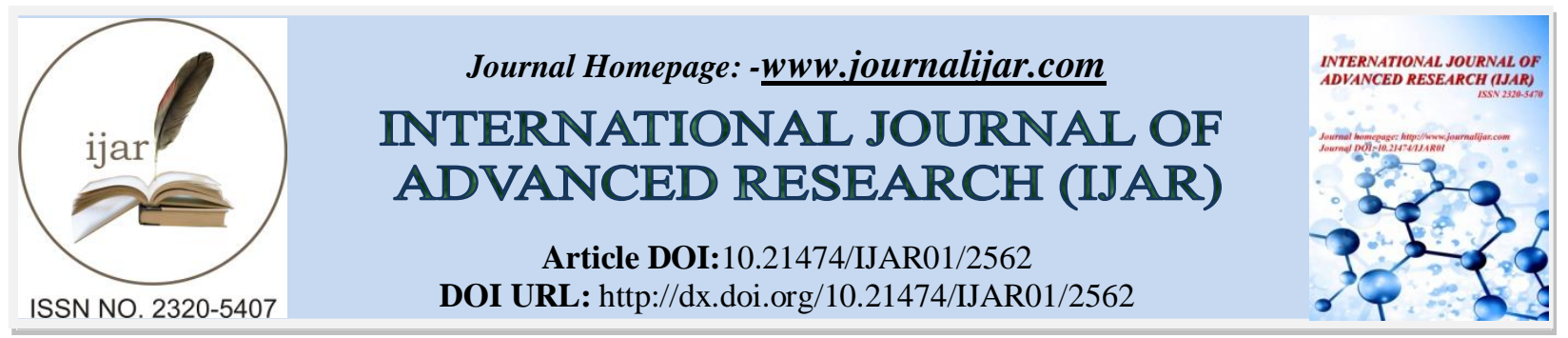

RESEARCH ARTICLE

\title{
DETERMINANTS AND PREDICTORS OF SMOKING CESSATION AMONG UNDERGRADUATE AND GRADUATE MEDICAL STUDENTS: A CROSS-SECTIONAL STUDY IN A PRIVATE MEDICAL COLLEGE.
}

\section{Dr. Mohammed J. Alyamani ${ }^{1}$, $Y a z e d$ A. Alkriadees ${ }^{2}$, Khaled A. Alkriadees ${ }^{2}$, Eman A. Sharahili ${ }^{2}$ and Abdulaziz M. Bin Mesained ${ }^{3}$.}

1. Associate Professor of Clinical and Hospital Pharmacy, Department of Clinical Pharmacy, College of Pharmacy, Al Maarefa Colleges.

2. Medical Students, College of Medicine, Al Maarefa Colleges.

3. Pediatrician resident, Pediatric Department, College of Medicine, Prince Sultan Military Medical City.

\section{Manuscript Info}

Manuscript History

Received: 27 October 2016

Final Accepted: 25 November 2016

Published: December 2016

Key words:-

Smoking cessation; cigarettes; smoker; ex-smoker; tobacco.

\section{Abstract}

Objectives: The present study aimed to assess the prevalence and predictors for smoking cessation among undergraduate and graduate students of medical college.

Methods: This cross-sectional study was conducted at a private Medical College in Riyadh, Saudi Arabia, from February 2016 to April 2016. A semi-structured questionnaire was administered to $2^{\text {nd }}$ to $6^{\text {th }}$ year and graduate medical students who were smokers or had quitted smoking during medical college. Demographic, academic and smoking assessment data was collected. Additionally, the contribution of medical knowledge in quitting smoking was assessed.

Results: The study included a total of 88 students (64 [72.7\%] males; 73 [83.1\%] aged below 25). Of these, $21.6 \%$ had quitted smoking during medical school, while the remainders continued smoking. Exsmokers' status was found to be associated with older age $(\mathrm{p}=0.002)$, superior academic level $(\mathrm{p}=0.026)$ and history of several quit attempts $(\mathrm{p}=0.047)$. The two groups were comparable in terms of duration, frequency, and amount of smoking. The number of students who reported to have acquired enough medical knowledge about smokingrelated pathologies was greater in current smokers $(92.8 \%)$ than in exsmokers (78.9\%); but without statistical significance.

Conclusion:The present study showed that more than one-fifth medical students quit smoking during medical college, and the likelihood to quit increases with age and academic level of the student and quit attempts in the past. No direct correlation between quitting smoking and acquired medical knowledge was reported; however, there is a possible correlation between quitting smoking and aquiring basic theoretical knowledge in the first 4 years.

Copy Right, IJAR, 2016,. All rights reserved. 


\section{Introduction:-}

The prevalence of smoking among healthcare professionals remains high despite of acquiring detailed knowledge of the harmful effects of smoking. ${ }^{1-3}$ This constitutes a real challenge to public health in regards to their key role in the fight against smoking. Studies have demonstrated that smoking healthcare professionals are less prone to provide smoking cessation advice to their patients, even to those with high risk comorbidities such as pregnant women or oral contraceptive users. ${ }^{4-6}$ The proficiency in providing such advice is even more affected in healthcare professionals who are highly dependent to nicotine. ${ }^{7}$

In Saudi Arabia, the prevalence of smoking behavior among medical students is estimated to be $19 \%$ to $25 \%$, which is relatively comparable to the smoking prevalence in other university students or general adult population. ${ }^{8-10}$ These observations contrast with the good knowledge among this specific population about smoking-related health hazard; which is sensibly more than the population average. ${ }^{8}$ The other issue behind that concern is the lack of effective training about tobacco dependence assessment and smoking cessation strategies among medical students. ${ }^{11}$ Besides the known health-related risks, smoking is associated with low academic achievements, poor grades and decreased educational attainment. ${ }^{12-15}$ In countries like Australia, the prevalence of smoking among healthcare professionals was found to be lower than in general population, ${ }^{16}$ while a decline in the incidence of smoking was observed among American medical students in last two decades. ${ }^{17}$ In other countries like Italy, the prevalence of smoking was reported to be higher than in general population. ${ }^{18}$

Nevertheless, psychology and behavior studies have demonstrated that acquiring awareness promotes decision making and helps resisting the temptations of smoking, thereby inducing the cognitive process of smoking cessation. Conversely, a positive perception towards smoking is associated with deprived decision-making and lack of selfefficacy. ${ }^{19,20}$ Therefore, there is more than one reason to expect a lower prevalence of smoking among medical student. Knowledge of the long-term detrimental consequences of smokinghelps in remodeling functional meaning of tobacco use and reinforces beliefs about individual and general harms of smoking.

This study estimated the prevalence of smoking quitters among undergraduate and graduate medical students and analyzed the correlation between acquiring medical knowledge of the harmful effects of smoking and the smoking cessation decision. In addition, further predictors of smoking cessation during medical school were analyzed.

\section{Methods:-}

This was a cross sectional study involving current smokers among medical students and those who quitted after receiving medical knowledge at AlMa'arefa Medical College, Ad Diriyah, Riyadh, Saudi Arabia. A semi-structured questionnaire was administered to all male and female undergraduate and graduate medical students who consented to participate in the study. Students were called to participate through an announcement and the flyers distributed among the students. The bilingual flyers (English and Arabic), briefly explained the objectives and importance of the study and participation modality. Participants who were unable to complete the questionnaire during working hours were offered the option of telephonic interview.

\section{Questionnaire:-}

The questionnaire was devided into 3 parts: 1) demographic and academic data, such as age, gender and student's level; 2) characteristics of smoking, such as age of initiation, duration of smoking and number of cigarettes smoked in a day ; 3) factors that may have correlation with quitting, such as perception about cigarette price, exposure to people who try to prevent from smoking, the existence of quit attempts, perceived negative effects of smoking and the most important motivation for smoking.

Data wascollected anonymously and the study was approved by the institutional review board of AlMa'arefa Medical College.

\section{Statistical analysis:-}

Data was analyzed through SPSS software (Version 21). Descriptive statistics were carried out to analyze the distribution of the population within the different variables' categories. Chi-square test and Fisher's exact test were undertaken to analyze correlation between nominal variables, including comparison between students who quitted smoking and those who did not. Binary logistic regression was carried out to analyze predictors of quitting smoking, 
using the student's smoking status (smoker, ex-smoker) as the dependent variable and relevant factors as independent variables in univariate and multivariate models. Statistical significance was set for a $\mathrm{P}<0.05$.

\section{Results:-}

\section{Population characteristics:}

The study included total 88 students, $64(72.7 \%)$ males and $73(83.1 \%)$ aged below 25 , and $19.3 \%$ in the $4^{\text {th }}$ year, $29.5 \%$ in $5^{\text {th }}$ year and $22.7 \%$ in $6^{\text {th }}$ year. Assessment of smoking status showed that $21.6 \%$ of the participants have quit smoking during the medical school, while the remainders continued smoking. In majority of smokers, age of smoking onset was between 15-21 years (68.2\%). Regarding use of tobacco, 65.9\% were daily smokers and one third $(35.2 \%)$ smoked or were smoking less than 10 cigarettes per day (Table 1).

Table 1:- Demographic and academic characteristics and smoking assessment of the population

\begin{tabular}{|c|c|c|c|}
\hline Variable & Category & Frequency & Percentage \\
\hline \multirow[t]{4}{*}{ Age (year) } & $18-21$ & 12 & 13.6 \\
\hline & $22-25$ & 61 & 69.3 \\
\hline & $26-29$ & 7 & 8.0 \\
\hline & $\geq 30$ & 8 & 9.1 \\
\hline \multirow[t]{2}{*}{ Gender } & Male & 64 & 72.7 \\
\hline & Female & 24 & 27.3 \\
\hline \multirow{7}{*}{ Position } & $2^{\text {nd }}$ year & 8 & 9.1 \\
\hline & $3^{\text {rd }}$ year & 7 & 8.0 \\
\hline & $4^{\text {th }}$ year & 17 & 19.3 \\
\hline & $5^{\text {th }}$ year & 26 & 29.5 \\
\hline & $6^{\text {th }}$ year & 20 & 22.7 \\
\hline & $7^{\text {th }}$ year & 4 & 4.5 \\
\hline & Graduate & 6 & 6.8 \\
\hline \multicolumn{4}{|l|}{ Smoking assessment } \\
\hline \multirow[t]{2}{*}{ Smoking status } & Current smoker & 69 & 78.4 \\
\hline & Ex-smoker & 19 & 21.6 \\
\hline \multirow[t]{3}{*}{ Age of onset of tobacco use } & $8-14$ years & 9 & 10.2 \\
\hline & $15-21$ & 60 & 68.2 \\
\hline & 22 or more & 19 & 21.6 \\
\hline \multirow[t]{3}{*}{ Duration of smoking } & $<1$ year & 9 & 10.2 \\
\hline & $1-5$ years & 50 & 56.8 \\
\hline & $>5$ years & 29 & 33.0 \\
\hline \multirow[t]{4}{*}{ Frequency of tobacco use } & Daily & 58 & 65.9 \\
\hline & Every 2-3 days & 15 & 17.0 \\
\hline & Once a week & 9 & 10.2 \\
\hline & Once a month & 6 & 6.8 \\
\hline \multirow[t]{3}{*}{ Number of cigarettes per day } & Up to 10 & 31 & 35.2 \\
\hline & $11-20$ & 35 & 39.8 \\
\hline & $>20$ & 11 & 12.5 \\
\hline \multirow[t]{4}{*}{ Type of tobacco used } & Cigarettes & 50 & 56.8 \\
\hline & Hubble-babble (Shisha) & 11 & 12.5 \\
\hline & Both & 26 & 29.5 \\
\hline & Others & 1 & 1.1 \\
\hline \multirow[t]{4}{*}{ Time of first daily cigarette } & Wake up & 36 & 40.9 \\
\hline & Lunch time & 17 & 19.3 \\
\hline & Dinner time & 25 & 28.4 \\
\hline & Before sleep & 10 & 11.4 \\
\hline \multirow{4}{*}{$\begin{array}{l}\text { Situations that produces urge to } \\
\text { smoke }\end{array}$} & Family & 9 & 10.2 \\
\hline & Friends & 45 & 51.1 \\
\hline & Solitude & 28 & 31.8 \\
\hline & Other & 6 & 6.8 \\
\hline
\end{tabular}

Factors associated with quitting among medical students 
Comparative analysis between current smokers and ex-smokers showed that smoking cessation was associated with advanced student's age $(\mathrm{p}=0.002)$ and superior academic level $(\mathrm{p}=0.026)$ (Figures 1, 2). Participants who reported to have acquired enough medical knowledge about smoking-related pathologies mainly belonged to the group of current smokers $(92.8 \%)$ than in ex-smokers (78.9\%); however, this result was not statistically significant. No difference was observed between the two groups regarding other smoking-related factors and smoking behaviors, such as duration of smoking ( $\mathrm{p}=0.663)$; frequency of smoking $(\mathrm{p}=0.0148)$; and amount of smoking $(\mathrm{p}=0.783)$ (Table 2).

Figure 1:- Correlation between student's age and smoking status

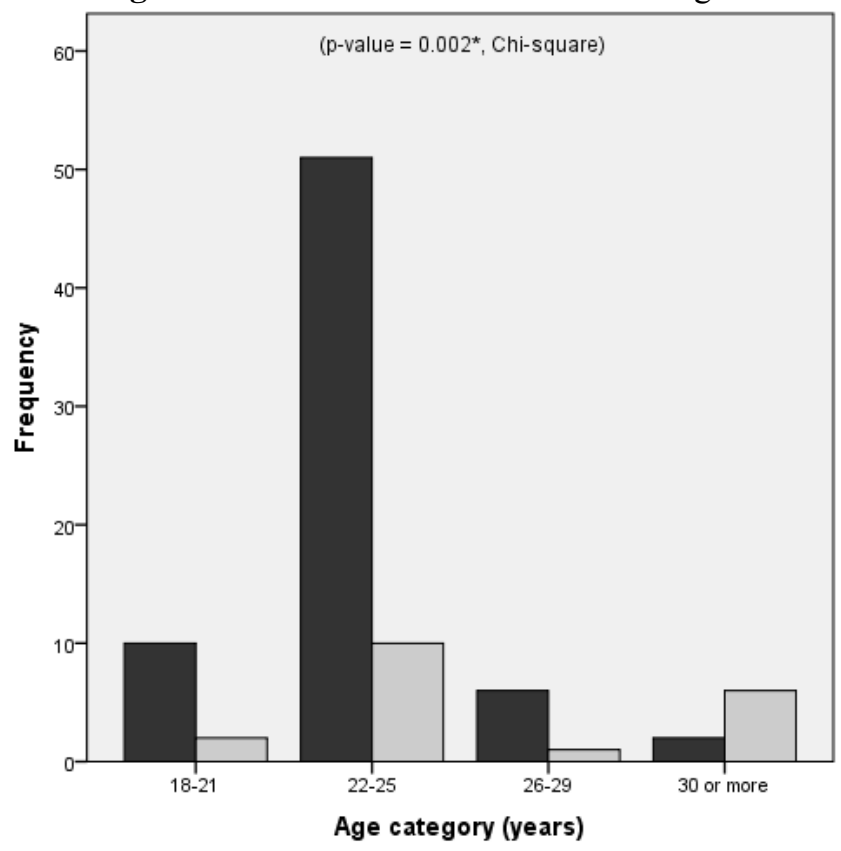

Smoking status

$\square$ Current smoker

$\square$ Ex smoker

Figure 2:- Correlation between student's level and smoking status

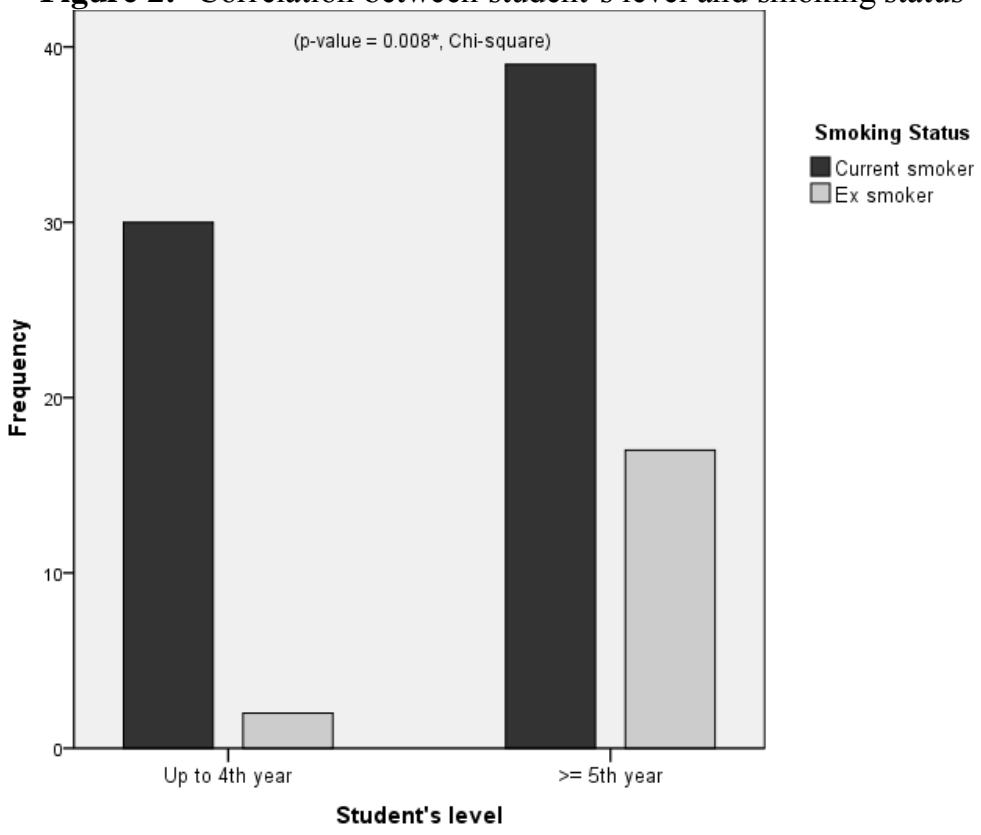


Table 2:- Factors correlated with quitting among ever smoker students

\begin{tabular}{|c|c|c|c|c|c|c|}
\hline \multirow[t]{2}{*}{ Factor } & \multirow[t]{2}{*}{ Category } & \multicolumn{2}{|c|}{ Current smokers } & \multicolumn{2}{|c|}{ Ex-smokers } & \multirow[t]{2}{*}{ p-value } \\
\hline & & Freq. & $\%$ & Freq. & $\%$ & \\
\hline \multirow[t]{4}{*}{ Age $(\text { year })^{1}$} & $18-21$ & 10 & 14.5 & 3 & 10.5 & \multirow[t]{4}{*}{$.002 *$} \\
\hline & $22-25$ & 51 & 73.9 & 10 & 52.6 & \\
\hline & $26-29$ & 6 & 8.7 & 1 & 5.3 & \\
\hline & $\geq 30$ & 2 & 2.9 & 6 & 31.6 & \\
\hline \multirow[t]{2}{*}{ Gender } & Male & 51 & 73.9 & 13 & 68.4 & \multirow[t]{2}{*}{.634} \\
\hline & Female & 18 & 26.1 & 6 & 31.6 & \\
\hline \multirow[t]{7}{*}{ Position } & $2^{\text {nd }}$ year & 7 & 10.1 & 1 & 5.3 & \multirow[t]{7}{*}{$.026^{*}$} \\
\hline & $3^{\text {rd }}$ year & 7 & 10.1 & 0 & 0.0 & \\
\hline & $4^{\text {th }}$ year & 16 & 23.2 & 1 & 5.3 & \\
\hline & $5^{\text {th }}$ year & 19 & 23.2 & 7 & 36.8 & \\
\hline & $6^{\text {th }}$ year & 14 & 27.5 & 6 & 31.8 & \\
\hline & $7^{\text {th }}$ year & 4 & 20.3 & 0 & 0.0 & \\
\hline & Graduate & 2 & 5.8 & 4 & 21.1 & \\
\hline \multirow{2}{*}{$\begin{array}{lll}\begin{array}{l}\text { Student's } \\
\text { categories })\end{array} & \text { level }\end{array}$} & Up to $4^{\text {th }}$ year & 30 & 43.5 & 2 & 10.5 & \multirow[t]{2}{*}{$.008 *$} \\
\hline & $\geq 5^{\text {th }}$ year & 39 & 56.5 & 17 & 89.5 & \\
\hline \multicolumn{7}{|l|}{ Smoking pattern } \\
\hline \multirow[t]{3}{*}{ Age of smoking onset } & 8-14 years & 7 & 10.1 & 2 & 10.5 & \multirow[t]{3}{*}{.473} \\
\hline & $15-21$ & 49 & 71.0 & 11 & 57.9 & \\
\hline & 22 or more & 13 & 18.8 & 6 & 31.6 & \\
\hline \multirow[t]{3}{*}{ Duration of smoking } & $<1$ year & 6 & 8.7 & 3 & 15.8 & \multirow[t]{3}{*}{.663} \\
\hline & $1-5$ years & 40 & 58.0 & 10 & 52.6 & \\
\hline & $>5$ years & 23 & 33.3 & 6 & 31.6 & \\
\hline \multirow[t]{2}{*}{ Continual smoking } & No & 21 & 30.4 & 10 & 52.6 & \multirow[t]{2}{*}{.0 .73} \\
\hline & Yes & 48 & 69.6 & 9 & 47.4 & \\
\hline \multirow[t]{2}{*}{ Frequency of tobacco use } & Daily smoker & 49 & 71.0 & 9 & 47.4 & \multirow[t]{2}{*}{.054} \\
\hline & Non-daily smoker & 20 & 29.0 & 10 & 52.6 & \\
\hline \multirow{2}{*}{$\begin{array}{l}\text { Number of cigarettes per } \\
\text { day }\end{array}$} & $\leq 10$ & 26 & 41.9 & 5 & 33.3 & \multirow[t]{2}{*}{.542} \\
\hline & $>10$ & 36 & 58.1 & 10 & 66.7 & \\
\hline \multirow[t]{4}{*}{ Type of tobacco used } & Cigarettes & 41 & 59.4 & 9 & 47.4 & \multirow[t]{4}{*}{.550} \\
\hline & Shisha & 7 & 10.1 & 4 & 21.1 & \\
\hline & Both & 20 & 29.0 & 6 & 31.6 & \\
\hline & Others & 1 & 1.4 & 0 & 0.0 & \\
\hline \multirow{2}{*}{$\begin{array}{l}\text { Time of first daily } \\
\text { cigarette }\end{array}$} & Wake up & 29 & 42.0 & 7 & 36.8 & \multirow[t]{2}{*}{.684} \\
\hline & Other & 40 & 58.0 & 12 & 63.2 & \\
\hline
\end{tabular}

* Statistically significant result $(\mathrm{p}<0.050)$.

Perceptions and attitudes correlated with quitting among medical students

Comparison of perception and attitude towards smoking and smoking cessation between the two groups showed that ex-smokers were more likely to have made several quit attempts $(\mathrm{p}=0.047)$. No other significant differences were observed between the two groups regarding other investigated parameters, such as perception about cigarettes' price $(\mathrm{p}=0.726)$; exposure to people who advice student to quit smoking $(\mathrm{p}=0.135)$; situations that urge to smoke $(\mathrm{p}=0.590)$; or motivations for smoking $(\mathrm{p}=0.191)$ (Table 3$)$. 
Table 3:- Smoking-related perceptions and attitude in ex-smokers by comparison to current smokers

\begin{tabular}{|c|c|c|c|c|c|c|}
\hline \multirow[t]{2}{*}{ Perception/attitude } & \multirow[t]{2}{*}{ Category } & \multicolumn{2}{|c|}{ Current smokers } & \multicolumn{2}{|c|}{ Ex-smokers } & \multirow[t]{2}{*}{ p-value } \\
\hline & & Freq. & $\%$ & Freq. & $\%$ & \\
\hline \multirow{4}{*}{$\begin{array}{l}\text { Situations that produces } \\
\text { urge to smoke }\end{array}$} & Family & 6 & 8.7 & 3 & 15.8 & \multirow[t]{4}{*}{.590} \\
\hline & Friends & 34 & 49.3 & 11 & 57.9 & \\
\hline & Solitude & 24 & 34.8 & 4 & 21.1 & \\
\hline & Other & 5 & 7.2 & 1 & 5.3 & \\
\hline \multirow[t]{2}{*}{ Cigarette price } & Not costly & 26 & 37.7 & 8 & 42.1 & \multirow[t]{2}{*}{.726} \\
\hline & Costly & 43 & 62.3 & 11 & 57.9 & \\
\hline \multirow{2}{*}{$\begin{array}{l}\text { Exposure to people who } \\
\text { try to prevent from } \\
\text { smoking }\end{array}$} & No & 17 & 24.6 & 8 & 42.1 & \multirow[t]{2}{*}{.135} \\
\hline & Yes & 52 & 75.4 & 11 & 57.9 & \\
\hline \multirow{2}{*}{$\begin{array}{l}\text { Medical knowledge } \\
\text { regarding pathology }{ }^{1}\end{array}$} & Not enough & 5 & 7.2 & 4 & 21.1 & \multirow{2}{*}{.079} \\
\hline & Enough & 64 & 92.8 & 15 & 78.9 & \\
\hline \multirow{2}{*}{ Quit attempts } & No & 25 & 36.2 & 2 & 10.5 & \multirow{2}{*}{$.047 *$} \\
\hline & Yes & 44 & 63.8 & 17 & 89.5 & \\
\hline \multirow{4}{*}{$\begin{array}{l}\text { Most influential person to } \\
\text { quit smoking }\end{array}$} & Father & 12 & 17.4 & 3 & 15.8 & \multirow[t]{4}{*}{.972} \\
\hline & Mother & 19 & 27.5 & 5 & 26.3 & \\
\hline & Brother & 5 & 7.2 & 2 & 10.5 & \\
\hline & Other & 33 & 47.8 & 9 & 47.4 & \\
\hline \multirow{2}{*}{$\begin{array}{l}\text { Are there new strategies to } \\
\text { persuade smokers to quit? }\end{array}$} & No & 21 & 30.4 & 9 & 47.4 & \multirow{2}{*}{.168} \\
\hline & Yes & 48 & 69.6 & 10 & 52.6 & \\
\hline \multirow{4}{*}{$\begin{array}{l}\text { Most negative effect of } \\
\text { smoking on smokers }\end{array}$} & Bad smell & 30 & 43.5 & 6 & 31.6 & \multirow[t]{4}{*}{.136} \\
\hline & Feeling of guilt & 16 & 23.2 & 9 & 47.4 & \\
\hline & Cough & 16 & 23.2 & 4 & 21.1 & \\
\hline & cost & 7 & 10.1 & 0 & 0.0 & \\
\hline \multirow{2}{*}{$\begin{array}{l}\text { Physicians helpful to } \\
\text { smoking cessation }\end{array}$} & No & 23 & 33.3 & 4 & 21.1 & \multirow[t]{2}{*}{$.404^{\ddagger}$} \\
\hline & Yes & 46 & 66.7 & 15 & 78.9 & \\
\hline \multirow{4}{*}{$\begin{array}{l}\text { Most important motivation } \\
\text { for smoking }\end{array}$} & Relief stress & 54 & 78.3 & 11 & 57.9 & \multirow[t]{4}{*}{.191} \\
\hline & Reinforce friendship & 6 & 8.7 & 4 & 21.1 & \\
\hline & $\begin{array}{l}\text { Affordability of } \\
\text { cigarette }\end{array}$ & 7 & 10.1 & 2 & 10.5 & \\
\hline & $\begin{array}{l}\text { Lack of education on } \\
\text { pathological effects of } \\
\text { smoking }\end{array}$ & 2 & 2.9 & 2 & 10.5 & \\
\hline \multirow[t]{2}{*}{ Stress factor } & Yes & 54 & 78.3 & 11 & 57.9 & \multirow[t]{2}{*}{$.085^{\ddagger}$} \\
\hline & no & 15 & 21.7 & 8 & 42.1 & \\
\hline
\end{tabular}

"Fisher's exact test; * statistically significant result $(P<0.050)$.

Predictors of smoking cessation during medical school

In both univariate and multivariate regression analysis, predictors of smoking cessation during medical school among medical students were age $\geq 30$ years $(\mathrm{OR}[95 \% \mathrm{CI}]=8.39[1.37 ; 51.27] ; \mathrm{p}=0.021)$; level $\geq 5^{\text {th }}$ year $(\mathrm{OR}$ $[95 \% \mathrm{CI}]=5.51[1.10 ; 27.58] ; \mathrm{p}=0.038)$; and history of multiple attempts to quit smoking (OR $[95 \% \mathrm{CI}]=5.33[1.03$; 27.54]; $\mathrm{p}=0.046$ ) (Table 4). 
Table 4:- Predictors for smoking cessation among medical students (binary logistic regression)

\begin{tabular}{|c|c|c|c|c|}
\hline \multirow{2}{*}{$\begin{array}{l}\text { Predictor / category } \\
\text { Univariate models } \\
\end{array}$} & \multirow[t]{2}{*}{ OR } & \multicolumn{2}{|c|}{$95 \% \mathrm{CI}$} & \multirow[t]{2}{*}{ p-value } \\
\hline & & & & \\
\hline \multicolumn{5}{|l|}{ Age } \\
\hline 18-21 (reference) & - & - & - & $.019 *$ \\
\hline $22-25$ & 0.98 & 0.19 & 5.17 & .981 \\
\hline $26-29$ & 0.83 & 0.06 & 11.28 & .981 \\
\hline$\geq 30$ & 15.00 & 1.65 & 136.17 & $.016^{*}$ \\
\hline \multicolumn{5}{|l|}{ Age } \\
\hline$<30$ years (reference) & - & - & - & - \\
\hline$\geq 30$ years & 15.46 & 2.81 & 85.23 & $.002 *$ \\
\hline \multicolumn{5}{|l|}{ Student's level } \\
\hline Up to $4^{\text {th }}$ year (reference) & - & - & - & - \\
\hline$\geq 5^{\text {th }}$ year & 6.54 & 1.40 & 30.52 & $<.001^{*}$ \\
\hline \multicolumn{5}{|l|}{ Quit attempts } \\
\hline No (reference) & - & - & - & - \\
\hline Yes & 4.83 & 1.03 & 22.65 & $.046^{*}$ \\
\hline \multicolumn{5}{|l|}{ Time of first cigarette } \\
\hline At wake-up (reference) & - & - & - & - \\
\hline Other & 1.24 & 0.44 & 3.54 & .684 \\
\hline \multicolumn{5}{|l|}{ Multivariate models } \\
\hline \multicolumn{5}{|l|}{ Age } \\
\hline$<30$ years (reference) & - & - & - & - \\
\hline$\geq 30$ years & 8.39 & 1.37 & 51.27 & $.021 *$ \\
\hline \multicolumn{5}{|l|}{ Student's level } \\
\hline Up to $4^{\text {th }}$ year (reference) & - & - & - & - \\
\hline$\geq 5^{\text {th }}$ year & 5.51 & 1.10 & 27.58 & $.038 *$ \\
\hline \multicolumn{5}{|l|}{ Quit attempts } \\
\hline No (reference) & - & - & - & - \\
\hline Yes & 5.33 & 1.03 & 27.54 & $.046 *$ \\
\hline
\end{tabular}

* Statistically significant result $(\mathrm{p}<0.050)$

\section{Discussion:-}

This cross-sectional study investigated the correlation between acquired medical knowledge and smoking cessation among medical students. It also analyzed other factors associated with smoking cessation by comparing demographic, academic and smoking-related factors between current smokers and ex-smokers. Results showed no correlation between quitting smoking and the principle factor, which was knowledge about smoking-related pathology as self-assessed by the participants. In addition, ex-smoker-to-current smoker ratio was 0.28 in this study sample, which may represent a low value in regards to the studying field and the status of future health professionals. Al-Turki et al. who also investigated smoking behavior in Saudi medical students found a higher exsmoker-to-current smoker ratio (0.41); however, only male students were included in the study. ${ }^{9}$ Another survey among Chinese medical students reported an even lower ratio of ex-smokers (0.14) with reference to current smokers. ${ }^{21}$ A study in Philadelphia, USA, showed a higher percentage of ex-smokers among nursing students $(17.8 \%)$ as compared to medical students $(9.8 \%) .{ }^{17}$ These relatively low rates of ex-smokers among medical students may indicate the low impact of the level of knowledge about smoking-related health risks on smoking behavior. This also suggests the existence of other determinants for smoking cessation that should be defined to improve awareness and reinforce quitting decision in this specific population.

On assessing the other factors, it was reported that student's age $(\geq 30)$ and advanced school year $\left(>4^{\text {th }}\right.$ year $)$ in addition to a history of multiple quit attempts were associated with higher smoking cessation rates. The $4^{\text {th }}$ year of medical school cut-off may advocate for the level of knowledge about smoking-related risks, as it coincides with the completion of theoretical teaching and clinical rotation of respiratory system, which includes the major part of smoking-related pathology. A longitudinal cohort study by Chaiton et al. demonstrated that it might take up to 30 attempts for an average smoker before successful quitting. ${ }^{22}$ Older studies have demonstrated that addictive 
substance consumption in adolescent was inversely correlated to the level of psychosocial maturity. ${ }^{23}$ Therefore, the significance of age may simply indicate the progression in time of the student's smoking behavior, as impacted by experience acquisition and intrapsychic conflict resolution, thereby resulting in multiple quit attempts before successful quitting. This also suggests that multiple quit attempts can be a natural process in the maturation of the quitting action.

Regarding patterns of tobacco use, we found that cigarettes were the most frequently used form of tobacco, with no difference between current and ex-smokers. Similarly, there was no difference in age of onset and duration of smoking, nor the number of daily cigarettes smoked. In Al-Turki's series, shisha (hubble-babble) was the most frequently used tobacco form with $44.1 \%$ of smokers, while cigarettes were used by $32.2 \%$ of the participants only. ${ }^{9}$ Conversely, occasional (non-daily) smoking was more frequently reported in the group of ex-smokers in our study, however, this was not statistically significant $(\mathrm{p}=0.054)$. This contrasts with findings from a study by Fagan et al., who investigated the quit attempts among American young adults and found that daily smokers were more prone to making quit attempts and expressing intention to quit. ${ }^{24}$ This difference could be explained by cognitive factors between the two populations' characteristics ; future health professionals may develop a harm reduction attitude in smoking, which associates reduction of smoking intensity and multiplication of quit attempts.

On the other hand, feeling of guilt was significantly prevalent in ex-smokers $(p=0.038$; results not presented in Tables). While the stress factor was more prevalent in current smokers, although not statistically significant $(\mathrm{p}=0.085)$. Feeling of guilt may contribute in smoking cessation and could be linked to religious motivation, as cigarette smoking is considered illicit in Muslim community. A study by Al-Kaabba et al., demonstrated that religious reasons were amongst the important motivations for not smoking among medical students in Riyadh, Saudi Arabia. ${ }^{25}$ Feeling of guilt could also be linked to other reasons, such as the risk to others, ${ }^{26}$ or more specifically the medical students' status of future health professional, who should exemplarily keep a healthy lifestyle. Several studies highlighted the contribution of stress as one of the major factors motivating for smoking and smoking onset and preventing from quitting. ${ }^{21,27}$ During medical school, stress can be induced or exacerbated by high effort-reward imbalance, with particularly high prevalence during the three first years where it could associate sub-depressive symptoms and abnormal behaviors including smoking. ${ }^{28,29}$ This might explain the lower proportion of smoking quitters in young-aged students as compared to older students.

The influence of peers is largely reported as a significant factor in smoking. ${ }^{9,30}$ In this study, no impact of the influence of peers or relatives on smoking cessation was reported. However, ex-smokers tended to be more exposed to people who tried to prevent them from smoking $(\mathrm{p}=0.135)$. An experiment that attempted to explain the mechanisms of peer influence on smoking behavior suggested that young adults' are generally attracted to smoking by passive imitation of their peers, rather than by an active incitation to smoke. ${ }^{31}$ This conclusion is supported by another study on adolescents that highlighted the positive impact of parents' non-smoking attitude in reducing the risk of smoking in their children. ${ }^{32}$ In this study, parent's smoking behavior was not assessed, while their active role did not show significant influence on quitting smoking among participants.

To summarize, these findings point toward an integrative multifactorial model, where common psychosocial factors interact with those specifically encountered in the target population. Population-specific factors included school issues, such as academic pressure; and cognitive factors such as the "more-than-the-average" knowledge about smoking-related health risks with regards to the study field. Therefore, specific actions are warranted to fight against medical students' smoking, in addition to common public actions. More targeted educational programs should be implemented in medical schools and innovative therapeutic techniques should be designed for medical students to help them quit smoking.

The limitations of the study included relatively small sample size, missing factors for simplification purpose and to increase participation rate, these included student's economic status, parents' educational level and smoking behavior,etc.,.

\section{Conclusion:-}

Less than 1 out of 4 medical students quit smoking during their medical school. No direct correlation between quitting decision and smoking-related medical knowledge was reported. These results are suggestive of the weak impact of the level of knowledge about smoking-related health risks on smoking behavior among medical students. 
Students who were more likely to quit smoking during medical school were those aged $\geq 30$, who had completed 4 years of study, and who had frequent quit attempts by the past.

A multifactorial model including population-specific and nonspecific determinants of smoking cessation should be established to guide specific preventive and therapeutic actions in fighting against smoking among medical students.

\section{References:-}

1. Krstev S, Marinković J, Simić S, Jovićević A, Marković-Denić L. Determinants of smoking and smoking cessation among health professionals in Serbia: A cross-sectional study. Vojnosanit Pregl. 2014;71(5):481-90.

2. Borgan SM, Jassim G, Marhoon ZA, Almuqamam MA, Ebrahim MA, Soliman PA. Prevalence of tobacco smoking among health-care physicians in Bahrain. BMC Public Health. BioMed Central; 2014;14(1):1.

3. Movsisyan NK, Arusyak H, Armen M, Frances SA. Smoking behavior, attitudes, and cessation counseling among healthcare professionals in Armenia. BMC Public Health. BioMed Central; 2012;12(1):1.

4. Barengo NC, Sandström HP, Jormanainen VJ, Myllykangas MT. Attitudes and behaviours in smoking cessation among general practitioners in Finland 2001. Sozial-und $\operatorname{Pr}\{\ddot{a}\}$ ventivmedizin. Springer; 2005;50(6):355-60.

5. Kawakami M, Nakamura S, Fumimoto H, Takizawa J, Baba M. Relation between smoking status of physicians and their enthusiasm to offer smoking cessation advice. Intern Med. 1997;36(3):162-5.

6. Abdulateef DS, Ali AJ, Abdulateef DS, Mohesh MIG. Smoking Knowledge, Attitude, and Practices Among Health Care Professionals from Sulaymaniyah City/Iraq. Tob use insights. Libertas Academica; 2016;9:1.

7. Zinonos S, Zachariadou T, Zannetos S, Panayiotou AG, Georgiou A. Smoking prevalence and associated risk factors among healthcare professionals in Nicosia general hospital, Cyprus: a cross-sectional study. Tob Induc Dis. BioMed Central; 2016;14(1):1.

8. Al-Haqwi AI, Tamim H, Asery A, others. Knowledge, attitude and practice of tobacco smoking by medical students in Riyadh, Saudi Arabia. Ann Thorac Med. Medknow Publications; 2010;5(3):145.

9. Al-Turki YA. Smoking habits among medical students in Central Saudi Arabia. Saudi Med J. 2006;27(5):7003.

10. Jradi H, Al-Shehri A. Knowledge about tobacco smoking among medical students in Saudi Arabia: Findings from three medical schools. J Epidemiol Glob Health. Elsevier; 2014;4(4):269-76.

11. Bassiony MM. Smoking in Saudi Arabia. Saudi Med J [Internet]. 2009 Jul [cited 2015 Jul 28];30(7):876-81. Available from: http://www.ncbi.nlm.nih.gov/pubmed/19617999

12. Cox RG, Zhang L, Johnson WD, Bender DR. Academic performance and substance use: findings from a state survey of public high school students. J Sch Health. Wiley Online Library; 2007;77(3):109-15.

13. Forrester K, Biglan A, Severson HH, Smolkowski K. Predictors of smoking onset over two years. Nicotine Tob Res. Oxford University Press; 2007;9(12):1259-67.

14. Tucker JS, Martinez JF, Ellickson PL, Edelen MO. Temporal associations of cigarette smoking with social influences, academic performance, and delinquency: a four-wave longitudinal study from ages 13-23. Psychol Addict Behav. American Psychological Association; 2008;22(1):1.

15. Jones SE, Axelrad R, Wattigney WA. Healthy and safe school environment, part II, physical school environment: results from the School Health Policies and Programs Study 2006. J Sch Health. Wiley Online Library; 2007;77(8):544-56.

16. Tobacco in Australia: Facts \& Issues - Chapter 1.12 Prevalence of smoking among health professionals [Internet]. 2014. Available from: http://www.tobaccoinaustralia.org.au/chapter-1-prevalence/1-12-futuresmoking-rates-

17. Patkar AA, Hill K, Batra V, Vergare MJ, Leone FT. A comparison of smoking habits among medical and nursing students. Chest. Elsevier; 2003;124(4):1415-20.

18. Ficarra MG, Gualano MR, Capizzi S, Siliquini R, Liguori G, Manzoli L, et al. Tobacco use prevalence, knowledge and attitudes among Italian hospital healthcare professionals. Eur J Public Health. Oxford Univ Press; 2010;ckq017.

19. Rodriguez D, Romer D, Audrain-McGovern J. Beliefs about the risks of smoking mediate the relationship between exposure to smoking and smoking. Psychosom Med. LWW; 2007;69(1):106-13.

20. of Health USD, Services H, others. Preventing tobacco use among youth and young adults: a report of the Surgeon General. Atlanta, GA US Dep Heal Hum Serv Centers Dis Control Prev Natl Cent Chronic Dis Prev Heal Promot Off Smok Heal. 2012;3.

21. Xiang H, Wang Z, Stallones L, Yu S, Gimbel HW, Yang P. Cigarette smoking among medical college students in Wuhan, People's Republic of China. Prev Med (Baltim). Elsevier; 1999;29(3):210-5.

22. Chaiton M, Diemert L, Cohen JE, Bondy SJ, Selby P, Philipneri A, et al. Estimating the number of quit attempts 
it takes to quit smoking successfully in a longitudinal cohort of smokers. BMJ Open. British Medical Journal Publishing Group; 2016;6(6):e011045.

23. Adalbjarnardottir S. Adolescent psychosocial maturity and alcohol use: Quantitative and qualitative analysis of longitudinal data. Adolescence. Libra Publishers Incorporated; 2002;37(145):19.

24. Fagan P, Augustson E, Backinger CL, O'Connell ME, Vollinger Jr RE, Kaufman A, et al. Quit attempts and intention to quit cigarette smoking among young adults in the United States. Am J Public Health. American Public Health Association; 2007;97(8):1412-20.

25. Al-Kaabba AF, Saeed AA, Abdalla AM, Hassan HA, Mustafa AA, others. Prevalence and associated factors of cigarette smoking among medical students at King Fahad Medical City in Riyadh of Saudi Arabia. J Fam Community Med. Medknow Publications; 2011;18(1):8.

26. Brozan N. RELATIONSHIPS; SMOKING AND GUILT. The New York Times [Internet]. 1981; Available from: http://www.nytimes.com/1981/03/09/style/relationships-smoking-and-guilt.html

27. Cohen S, Lichtenstein E. Perceived stress, quitting smoking, and smoking relapse. Heal Psychol. Lawrence Erlbaum Associates; 1990;9(4):466.

28. Ludwig AB, Burton W, Weingarten J, Milan F, Myers DC, Kligler B. Depression and stress amongst undergraduate medical students. BMC Med Educ. BioMed Central; 2015;15(1):1.

29. Kouvonen A, Kivimäki M, Virtanen M, Pentti J, Vahtera J. Work stress, smoking status, and smoking intensity: an observational study of 46190 employees. J Epidemiol Community Health. BMJ Publishing Group Ltd; 2005;59(1):63-9.

30. Tobacco in Australia: Facts \& Issues - Chapter 8.2.The smoking behaviour of peers, and peer attitudes and norms [Internet]. 2014 [cited 2016 Oct 7]. Available from: http://www.tobaccoinaustralia.org.au/chapter-5uptake/5-8-the-smoking-behaviour-of-peers-and-peer-attitu

31. Harakeh Z, Vollebergh WAM. The impact of active and passive peer influence on young adult smoking: An experimental study. Drug Alcohol Depend. Elsevier; 2012;121(3):220-3.

32. Simons-Morton BG, Farhat T. Recent findings on peer group influences on adolescent smoking. J Prim Prev. Springer; 2010;31(4):191-208. 